\title{
Double-doughnut Sign: An Interesting Imaging Finding in Dengue Encephalitis
}

\author{
Çift Halka Bulgusu: Dang Hastalığı Ensefalitinde İlginç Bir Görüntüleme Bulgusu
}

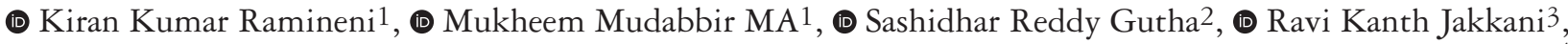
(1) B Saroj Kumar Prusty 4

${ }^{1}$ Yashoda Hospital, Clinic of Neurology, Hyderabad, India

${ }^{2}$ Yashoda Hospital, Clinic of Medicine, Hyderabad, India

${ }^{3}$ Yashoda Hospital, Clinic of Radiology, Hyderabad, India

4 Yashoda Hospital, Clinic of Critical Care, Hyderabad, India
\end{abstract}

Keywords: Dengue, doughnut, encephalitis, magnetic resonance imaging

Anahtar Kelimeler: Dang, halka, ensefalit, manyetik rezonans görüntüleme

Dear Editor,

A 14-year-old girl was brought to the emergency department with a history of fever for five days, two episodes of seizures, followed by altered sensorium of one day's duration. She was febrile, stuporous with a Glasgow Coma scale score of 10 and with terminal neck stiffness. Possibility of meningoencephalitis was considered and was started on intravenous levetiracetam and ceftriaxone. A hemogram revealed hemoglobin of $12 \mathrm{~g} /$ $\mathrm{dl}$, total leukocyte count $3500 / \mathrm{mm}^{3}$, platelet count of $76,000 /$ $\mathrm{mm}^{3}$. Other laboratory parameters were random blood sugar of $86 \mathrm{mg} / \mathrm{dl}$, and serum creatinine $0.8 \mathrm{mg} / \mathrm{dl}$. Serum electrolytes, calcium, magnesium, and liver function tests were within normal limits. Serum dengue immunoglobulin (Ig)-M was strongly positive. Evaluation for differentials including Japanese encephalitis, leptospira, scrub typhus, and malaria was negative.

Magnetic resonance imaging of the brain showed extensive parenchymal changes involving bilateral thalami, the brainstem, and cerebellar white matter. Bilateral thalamic lesions were T1 hypointense, T2 and fluid attenuated inversion recovery (FLAIR) hyperintense with central diffusion restriction, haemorrhages on $\mathrm{T} 2 *$ gradient recalled echo sequence giving the appearance of a double-doughnut. Post-contrast images revealed subtle enhancement (Figure $1 \mathrm{a}, \mathrm{b}, \mathrm{c}, \mathrm{d}, \mathrm{e}, \mathrm{f}$ ).

Cerebrospinal fluid analysis showed normal protein $(18 \mathrm{mg} /$ $\mathrm{dl})$, sugar $(78 \mathrm{mg} / \mathrm{dl})$ and 6 cells $/ \mathrm{mm}^{3}$ with all lymphocytes, no atypical cells were seen, and a meningoencephalitis panel including herpes simplex virus 1 and 2 polymerase chain reaction was negative. Sensorium improved significantly by day 3 of admission with conservative management and supportive care, and by day 5 she was ambulant. Thrombocytopenia improved over the next week and she was discharged in a stable condition. At the one month follow-up, she was asymptomatic.

Neurologic complications of Dengue fever include encephalopathy, encephalitis, Guillain-Barre syndrome, transverse myelitis, and neuromuscular disorders (1). Various pathogenic mechanisms include direct viral invasion, the systemic inflammatory response, and immune-mediated mechanisms. In our patient, acute febrile illness with encephalopathy, seizures, and positive dengue $\operatorname{IgM}$ serology and exclusion of mimickers satisfied the previously defined diagnostic criteria of Dengue encephalitis (2).

Commonly affected areas in Dengue encephalitis include the thalami, basal ganglia, brain stem, and cerebellar and cerebral hemispheres $(3,4)$. The lesions are typically hypointense on T1

Address for Correspondence/Yazışma Adresi: Mukheem Mudabbir MA MD, Yashoda Hospital, Clinic of Neurology, Hyderabad, India Phone: +919701944000 E-mail: dr.mudabbir@gmail.com ORCID: orcid.org/0000-0002-4347-0964

Received/Geliş Tarihi: 26.02 .2020 Accepted/Kabul Tarihi: 22.05 .2020

${ }^{\circ}$ Copyright 2020 by Turkish Neurological Society

Turkish Journal of Neurology published by Galenos Publishing House. 

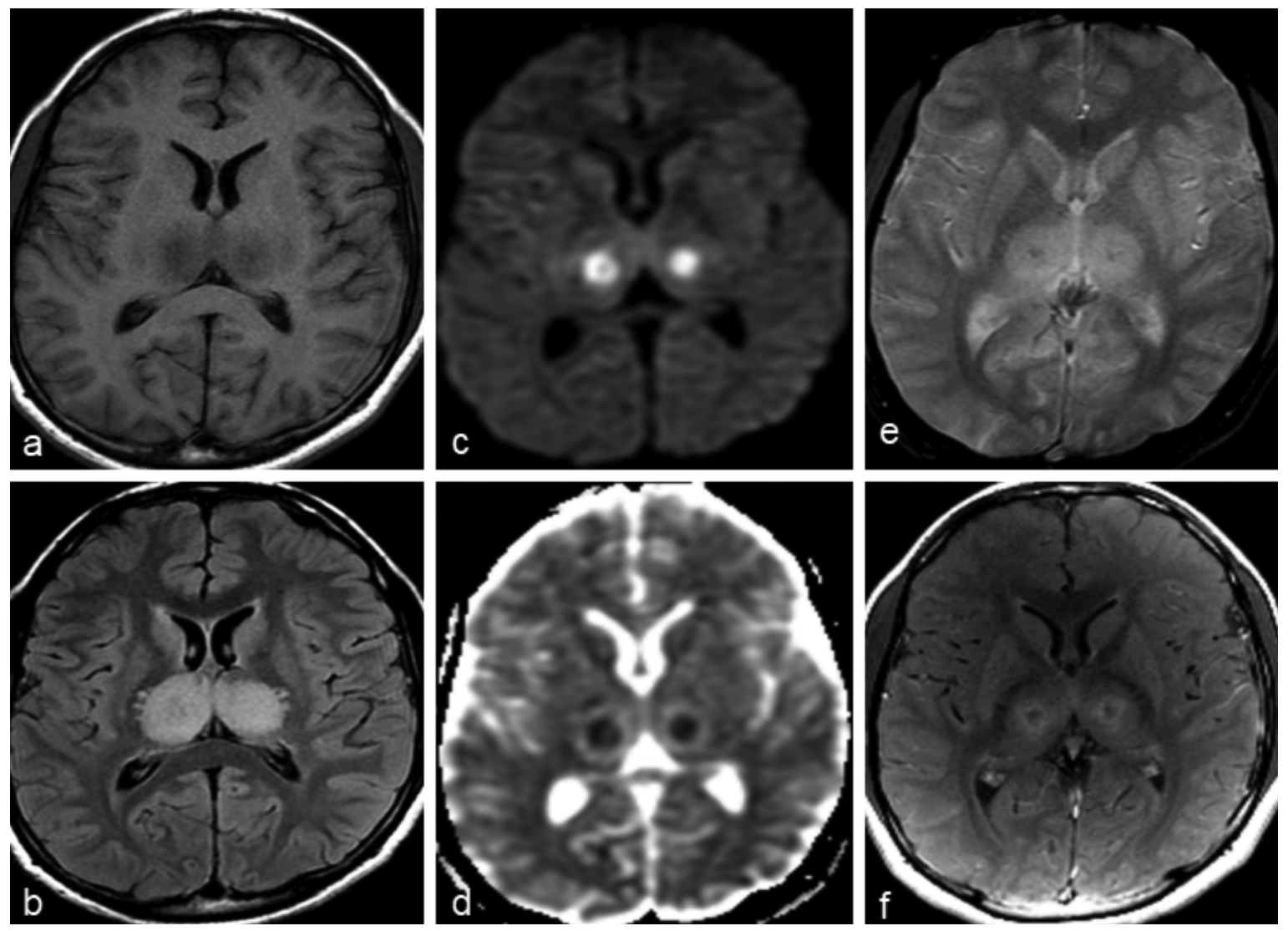

Figure 1. MRI brain a) T1-image shows symmetrical hypo intensities in bilateral thalami, b) symmetrical hyperintensities in bilateral thalami in FLAIR image, c, d) diffusion restriction at the centre of bilateral thalamic lesions in DWI image with corresponding ADC signal changes, e) T2* GRE image shows blooming in the centre of bilateral thalami giving the appearance of double-doughnut, $\mathrm{f}$ ) post-contrast image shows enhancement surrounding the central thalamic hypointensity

MRI: Magnetic resonance imaging, FLAIR: Fluid attenuated inversion recovery, DWI: Diffusion weighted image, ADC: Apparent diffusion coefficient, GRE: Gradient recalled echo

and hyperintense on T2 and FLAIR images with patchy areas of diffusion restriction $(3,4)$. Very few reports described this typical imaging finding of double-doughnut sign in Dengue infections (5). Similar findings are rarely described in other viral infections such as Japanese encephalitis. In conjunction with typical clinical features and thrombocytopenia, these imaging findings help in timely diagnosis and appropriate management of Dengue encephalitis, especially in endemic zones.

\section{Ethics}

Informed Consent: Informed consent was taken from both the parents of patient.

Peer-review: Externally peer-reviewed.

\section{Authorship Contributions}

Surgical and Medical Practices: K.K.R., M.M.M.A., Concept: K.K.R., M.M.M.A., Design: K.K.R., M.M.M.A., Data Collection or Processing: S.R.G., R.K.J., Analysis or Interpretation: K.K.R., M.M.M.A., Literature Search: M.M.M.A., B.S.K.P., Writing: K.K.R.
Conflict of Interest: No conflict of interest was declared by the authors.

Financial Disclosure: The authors declared that this study received no financial support.

\section{References}

1. Carod Artal FJ, Wichmann O, Farrar J, Gascon J. Neurological complications of dengue virus infection. Lancet Neurol 2013;12:906-919.

2. Soares CN, Marzia PS. Diagnosis criteria of dengue encephalitis. Arq Neuropsiquiatr 2014;72:263

3. Soni BK, Das DSR, George RA, Aggarwal R, Sivasankar R. MRI features in dengue encephalitis: a case series in South Indian tertiary care hospital. Indian J Radiol Imaging 2017;27:125-128.

4. Jugpal TS, Dixit R, Garg A, et al. Spectrum of Şndings on magnetic resonance imaging of the brain in patients with neurological manifestations of dengue fever. Radiol Bras 2017;50:285-290.

5. Singh H, Dhibar DP, Mittal DK, Jain A. Double doughnut sign in dengue encephalitis, QJM: An International Journal of Medicine 2019;112:813814. 